УДК 130.2

doi: $10.32620 / \mathrm{gch} .2018 .2 .05$

Проценко О. П., Солошенко О. М.

\title{
ДУХОВНІСТЬ: СУТНІСТЬ, ІСТОРИЧНІ ВИТОКИ ТА СУЧАСНИЙ ВИМІР
}

Статтю присвячено проблемі духовності, яка в умовах сучасного украӥнського суспільства по-новому потрібна. Цей феномен розглянуто з погляду його структури й існування в дихотомії минулого та сучасного. Проаналізовано роль біблійних заповідей $і$ їхню транслячію в аксіосферу сучасного суспільства, а також у життєвий простір людини. Особливу увагу приділено аналізу трансформацї духовних иінностей у практичну площину сучасної освітньої стратегії закладу вищої освіти Украӥни.

Ключові слова: духовність, ијнність, традиція, заповідь, освіта, виховання.

The article is devoted to the problem of spirituality, which in the conditions of modern Ukrainian society has acquired special relevance. This phenomenon is presented in terms of its structure and existence in the dichotomy of the new and the present. The role of biblical commandments and their translation into the axiosphere of modern society, as well as into the vital space of man, is indicated. Particular attention is paid to the transformation of spiritual values into the plane of the modern educational strategy of the higher school of Ukraine.

Keywords: spirituality, value, tradition, commandment, education, upbringing.

Статья посвящена проблеме духовности, которая в условиях современного украинского общества приобрела особую востребованность. Данный феномен представлен с точки зрения его структуры и существования в дихотомии пришлого и настоящего. Указана роль библейских заповедей и наставлений и их транслячия в аксиосферу современного общества, а также в жизненное пространство человека. Особое внимание уделено трансформации духовных иенностей в плоскость современной образовательной стратегии высшей школь Украины.

Ключевье слова: духовность, ценность, традиция, заповедь, образование, воспитание.

Постановка проблеми. Проблема духовності завжди актуальна як у теоретичному, так і в практичному вимірі. Але особливої уваги вона потребує в змінні епохи суспільства, коли для людини конче загострюються питання сенсу життя, ціннісних пріоритетів, етнічної й релігійної ідентичності.

Наукові дослідження феномена духовності знайшли гідне місце в працях зарубіжних авторів, серед яких К.-О. Апель, Г. Йонас, П. Слотердайк, Ю. Габермас, Ф. Фукуяма. Привертають увагу концептуальні розроблення зазначеної теми представниками вітчизняної філософської думки, такими як Л. Газнюк, М. Култаєва, В. Мищенко, А. Олексієнко, І. Степаненко, О.К. Чаплигін, А. Шевченко та ін.

Спираючись на ступінь розробленості проблеми в межах філософських досліджень і методів філософського аналізу, сформульована мета статті - виявити аксіологічну спрямованість духовності й на підставі сутнісних характеристик цього феномена репрезентувати його в стратегічні напрямки вищої освіти сучасного 
українського суспільства.

Виклад основного матеріалу. У сучасному гуманітарному знанні духовність розглядають як складний системний феномен, який акумулює в себе певні компоненти й існує на різних рівнях індивідуальної й суспільної свідомості, визначає себе в різних формах існування, у яких людина перетворює себе й навколишній світ за такими вимірами, як дух - душа - духовність на противагу матерії - матеріальному - тілесному.

Механізмом створення духовності є свідомість і самосвідомість як здатність людини розуміти себе й поглянути на себе очима інших, передбачати майбутнє. На розвиток самосвідомості в історичному контексті значно вплинули релігійна віра, моральні вимоги, естетичні норми, філософський і науковий світогляди. Саме вони й зараз підтримують здатність людини створювати високі ціннісні пріоритети, можливість гармонізувати стосунки, упорядковувати повсякденне буття. Як зазначає дослідник Г.П. Вижлєцов, низький розвиток ціннісної свідомості і є однією головних ознак соціальної кризи взагалі [2, с. 3].

Духовність як складний i багатофункціональний феномен, як прояв суто людського існування демонструє три рівні: раціональний, емоційний i комунікативний. Перший рівень охоплює систему знання про навколишній природний світ, аксіосферу соціуму, розуміння про людину й сенс ії буття. Він існує як інтелектуально-інформаційний потенціал людини. Другий рівень уміщує в себе комплекс відчуттів, вражень і переживань людини стосовно самої себе та свого місця в цілому світі. Третій, комунікативний рівень визначений навичками стійких відносин i стосунків, певних соціальних практик, стереотипів поведінки, нормативних дій i вчинків. Саме він фіксує духовне, дає йому наочне, реальне існування.

Витоки духовності в європейській культурі спостерігаються в ранні роки Середньовіччя. У ті часи «...треба було знайти такі розумові та поведінкові парадигми, які не тільки би переводили християнську ідеологію на мову звичних $\mathrm{i}$ традиційних форм культури, але й змінювали ідейний зміст самої культури» [3, c. 216]. Отже, Біблію розглядали як програму, відповідно до якої слід здійснювати життя людини. Завдання теоретичних досліджень у філософії того часу полягало в тому, щоб донести до людей зміст священних писань, розтлумачити закладену в них мудрість, обгрунтувати постулати й заповіді. Із поширенням християнства необхідно було створити зримі поведінкові варіанти, що однозначно виражають його основні духовні цінності: віру, любов, терпіння, смиренність, усепрощення, аскетизм - i наочно підтримати їх. У статусі порад і повчань вони набувають нормативного змісту, стають універсальними й доступними широкому колу людей за межами релігійної свідомості. Читаючи тексти Біблії, можна відчути сучасне звучання порад, які там містяться. Наведені в текстах вимоги до поведінки передбачають піднесений розвиток моральної свідомості й психологічної рефлексії, визначений рівень здатності людини до самоконтролю й самообмеження.

Читаючи тексти Біблії, можна відчути сучасне звучання порад, які там містяться. Вони нібито формують найбільш типові факти соціальної активності людини, забезпечують ій необхідні комплекси відчуттів, навичок самовираження й 
спілкування. Ці вимоги існують як заповіді або настанови: «...Заповідь є світильник, i настанова - світло, і напутливі повчання - шлях до життя» (Притчі, розд. 12,1). Наведені в текстах Біблії вимоги до поведінки, яка грунтується на таких духовних якостях людини, як совість, провина, відповідальність тощо. Саме вони здатні впливати на самоконтроль і самообмеження людини й регулювати стосунки дружби, сусідства, споріднення: «Хто хоче мати друзів, той сам має бути дружнім: і буває друг ближче пов'язаний ніж брат» (Притчі, розд. 18, 24); «Не вчащай входити до будинку друга твого, щоб ти не наскучив йому і він не зненавидів тебе» (Притчі, розд. 25, 17).

Серед повчань $є$ такі, що навчають мистецтву спілкування, сприяють дотриманню таких форм поведінки, які створюють позитивну й доброзичливу морально-психологічну атмосферу i, таким чином, можуть заподіяти зло навколишнім і самому собі: «Мудрий боїться й віддаляється від зла, а дурний дратливий та самовпевнений» (Притчі, розд. 14, 16).

Зміст повчань пояснює, які риси характеру й почуття людини можна розглядати як похвальні й сприятливі. Вони й дотепер є прикметами високої духовної культури людини. Це розсудливість, скромність, стриманість, терпимість, уміння додержуватися обіцянки, зберігати мовчання, бути поблажливим до вчинків інших. «Краще тобі не обіцяти, ніж обіцяти й не виконувати» (Еккл., розд. 5, 4), «Не будь занадто строгим і не виставляй себе занадто мудрим» (Еккл., розд. 16).

Представниками філософії Середньовіччя ставилося й у певному сенсі розв’язувалося питання щодо механізму формування образу дій гідного християнина. Ідея Божої благодаті як достатньої підстави для додержування заповідей посідає значне місце й у міркуваннях Августина й Хоми Аквінського.

Прагнення досягати великої гармонії внутрішнього й зовнішнього в поведінці людини, що присвятила себе вірі, знаходить вираження в понятті «святість». Середньовічні святі повинні були мати комплекс таких духовних якостей, як дружелюбність, мудрість, чесність, помірність, радісність. При цьому фізична краса людини цінувалася так само високо, як і духовна [1].

Із виникненням християнства взаємовплив культур Сходу й Заходу стає особливо помітним. Із поширенням біблійних текстів норми пристойної поведінки набули подальшого вербального оформлення, частково втратили релігійне забарвлення й стали універсальними засобами спілкування людей, які безпосередньо впливають на адаптацію людини до соціуму, на форми іiі виховання, просвітництва й освіти.

Сьогодні в Україні активно відбуваються процеси національного розвитку: відроджуються й вшановуються кращі надбання української історії та духовної культури українського народу. На шляху євроінтеграції України в єдиний освітній простір особливого значення набуває комплексне й гармонійне поєднання освітніх i виховних компонентів навчального процесу. Освіта XXI ст. призначена не лише надавати певний обсяг знань, а безпосередньо впливати на становлення духовної особистості, здатної до креативного критичного мислення, відповідальної за свої дії, справедливої та толерантної.

Виховний вектор сучасного освітнього процесу грунтується на пріоритетних 
позиціях патріотичного виховання, на принципах історичної пам'яті, спрямований на збереження духовних цінностей українців: любові до рідної землі, до родини й родинних стосунків, до справжніх взаємин дружби й взаємодопомоги, здатності зберігати свою національну культуру й брати активну участь у політичних i економічних напрямках держави, міжнародних відносинах.

Розмірковуючи про архетипи національної культури, український дослідник Н. Хамітов зазначає: специфіка людського буття полягає в тому, що внутрішні первісні комунікативні особистісні стосунки набувають етнонаціональних виявів i зумовлюють самоідентичність людини. При цьому «...архетип колективного позасвідомого та архетип національної культури виражають дві різних сфери, або, точніше, два різних рівня людської реальності - донаціонального й національного буття» [4, с. 404]. У цьому складному процесі традиції постійно трансформуються, інновації через компромісні форми перетворюються на традиції, які акумулюють у собі потреби, інтереси, ціннісні орієнтири. Таким чином відбувається передання культурного надбання, гарантується живий зв'язок поколінь, формується самосвідомість народу та його ідейний потенціал як головний вектор державної політики.

Повсякденне буття становить сполучну ланку часу. Воно забезпечує спілкування 3 іншими, тому що буденне життя насичене обрядами, ритуалами, традиціями. Це єдиний дієвий простір, де людина не самотня, де в неї є віра, мова, звичні та прийнятні форми поведінки. Таким чином повсякденність несе інформацію про минуле, що впливає на теперішнє й майбутнє суспільство, у якому людина вихована й здобула своє національне коріння.

Для культури побуту українського етносу характерним є мистецьке оздоблення. Воно було й залишається своєрідним засобом узагальнення життєвого досвіду зі втіленням народної мудрості, світогляду й ідеалів поколінь. Останнє виражає себе в зрозумілих настановах суспільного буття, відображених у витворах мистецтва, наприклад, у сучасній естрадній пісні «Одна калина» на слова В. Куровського: «Крапля море не заллє. Наливай, козаче, бо у нас ще є одна калина під вікном, одна родина за столом, одна стежина, що додому йде сама, одна любов на все життя, одна журба до забуття та Україна, бо в нас іншої нема». Національна ідея грунтується на універсальних цінностях людського буття, а народна культура стає фундаментом будь-якої стратегічної лінії в політиці держави, оскільки зумовлює солідарність і взаєморозуміння між людьми в масштабах держави й суспільства в цілому.

У межах гуманізації освіти в закладах вищої освіти України, і перш за все технічних, реформування освітньо-виховного процесу має різне спрямування й призначення. Найголовніша роль у ньому належить соціально-гуманітарним дисциплінам, які, 3 огляду на освітньо-професійне призначення, забезпечують формування соціокультурних, комунікативних, громадянських компетентностей майбутнього фахівця.

Висновок. У наш час проблема духовності залишається актуальною й вагомою як у науково-теоретичному, так і в практичному значенні. Незважаючи на досить високий ступінь розроблення й широке розповсюдження цієї проблеми, у 
соціогуманітарному знанні ще залишаються відкритими питання, пов'язані 3 морфологічним змістом феномена духовності та його показниками в реальній діяльності індивіда й розширенні аксіосфери сучасного українського суспільства. Отже, у прикладному аспекті слід приділяти увагу визначенню концептуальних засад освітньо-виховного процесу взагалі й у закладах вищої освіти зокрема. Це, головним чином, пов'язано 3 тим, що викладання дисциплін соціогуманітарного циклу має ідейне підгрунтя загальнолюдських пріоритетних цінностей.

\section{Лiтература:}

1. Антология мировой философии : в 4 т. / Ин-т филос. М., 1969. Т. 1, Ч. 2 : Философия древности и средневековья. 1969. 376 с.

2. Выжлецов Г. П. Аксиология культури. СПб. : Изд-во Санкт-Петербургского университета, 1996. $152 \mathrm{c}$.

3. Гусейнов А. А., Иррлити Г. История этики. М. : Мысль, 1987. 589 с.

4. Хамітов Н. Людина і народ: етноантропологія // Хамітов Н. Філософія: Світ людини. Київ : Либідь, 2003. 432 с.

\section{Olga Protsenko, Olena Soloshenko}

\section{SPIRITUALITY: ESSENCE, HISTORICAL ORIGIN AND MODERN MEASUREMENT}

Nowadays, the problem of spirituality remains relevant and significant for sociohumanitarian knowledge, both in scientific-theoretical and in applied dimension. There are still open questions related to the morphology of the phenomenon of spirituality, its indicators in the real activity of individuals and the expansion of the axiosphere of modern society.

On the basis of the development of the problem of spirituality within the boundaries of philosophical knowledge, as well as the use of basic methods of philosophical analysis, the goal of the article is to analyze the axiological orientation of spirituality and, based on the essential characteristics of this phenomenon, to predict structural changes in the strategy of modern higher education.

It is indicated that spirituality is prefaced by the activity of consciousness, the ability of a person to reflect, which makes it possible to remain an individual, being among others.

Spirituality, as a complex and multifaceted phenomenon, as a unique manifestation of human existence, exists on three levels. The first is rational. It is an information and intellectual resource, where knowledge about the world around us and the place of the person in it is generalized. The second level - emotional, contains a complex of feelings and experiences; and the third - a communicative level, summarizes skills, behavioral stereotypes, norms of actions and deeds, due to which social interaction is carried out.

It is noted that the origins of the spiritual culture go back into the epoch of the early 
Middle Ages, when the biblical commandments and teachings were regarded as those that should be implemented. They pointed to the laudable traits of character and actions, which even now are a sign of a high spiritual culture of a person: modesty, prudence, restraint, hard work, etc. With the spread of the biblical texts, the commandments and instructions acquired further verbal design, partially or completely losing religious content, becoming universal methods of communication and indicators of the spiritual culture of modern man. At present, they affect the adaptation of man to society, the forms of upbringing, education and enlightenment.

It is noted that the strategy of higher education in Ukraine is based on the priorities of historical memory, aimed at preserving the spiritual values of the Ukrainians. It is noted that in this complex process of tradition, they are constantly transmitted, innovations are transformed into traditions, acquiring sustainability, accumulating in themselves the needs, interests and values of people.

Проценко Ольга Петрівна - доктор філософських наук, професор, професор кафедри суспільно-гуманітарних дисциплін Харківського національного університету будівництва та архітектури.

Солошенко Олена Михайлівна - кандидат історичних наук, доцент, завідувач кафедри суспільно-гуманітарних дисциплін Харківського національного університету будівництва та архітектури.

Надійшла до редакції 14.06.2018. Розглянута на редколегії 25.06.2018.

\section{Рецензенти:}

Доктор філософських наук, професор XAI, професор кафедри філософії Національного аерокосмічного університету ім. М.С. Жуковського «ХАІ» Кузнецов А.Ю.

Кандидат філософських наук, доцент, доцент кафедри філософії Національного аерокосмічного університету ім. М.Є. Жуковського «ХАІ» Широка С.I. 